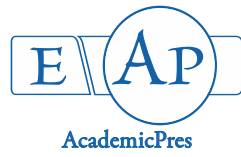

\title{
Diversity, Distribution and Conservation Status of the Genus Tectaria Cav. from Deccan Peninsula and Western Ghats of India
}

\author{
Sachin M. PATIL ${ }^{1}$, Raju ANTONY², Santhosh NAMPY3, \\ Kishore S. RAJPUT ${ }^{1 *}$ \\ ${ }^{1}$ The M. S. University of Baroda, Department of Botany, Laboratory of Plant Anatomy \& Pteridology, Vadodara 390002 , \\ India;sach2010d@gmail.com; ksrajput-botany@msubaroda.ac.in ("correspondingauthor) \\ ${ }^{2} J a w a h a r l a l$ Nehru Tropical Botanic Garden and Research Institute (JNTBGRI), Palode, Thiruvananthapuram, Kerala 695562, \\ India; rajuantonytbgri@rediffmail.com \\ ${ }^{3}$ University of Calicut, Department of Botany, Thrissur, Calicut Road, Thenhipalam, Kerala 673635, India; santhoshnampy@yahoo.com
}

\begin{abstract}
The halberd fern genus Tectaria Cav., is terrestrial, medium to large size herb, growing along the cut edges of hills and hillocks or edges of river. It is characterized by the presence of erect, creeping or suberect rhizome with dimorphic, subdimorphic or monomorphic fronds and anastomosing to free veins. Generally, it occurs in different habitats of the tropical to subtropical region of the world. Different members are exploited for various purposes in traditional medicinal system by local tribes. However, the diversity, distribution, conservation status and state of the knowledge about Tectaria (Tectariaceae) is not uniform worldwide including India. Therefore, the present investigation aims to study the diversity, distribution and conservation status of this genus from Peninsula and Western Ghats of India. Out of 24 species reported from India, nearly nine species occur in Deccan Peninsula and Western Ghats. A detailed distribution and conservation status with the identification key to the species of Tectaria distributed in this region is provided herewith.
\end{abstract}

Keywords: biogeography; homosporous; near threatened; pteridophytes; Tectariaceae

\section{Introduction}

The genus Tectaria Cav. (Tectariaceae) is a perennial, herbaceous, homosporous fern, well distributed in tropical and subtropical regions with most species growing terrestrially in rain forests along the cut surfaces or hilly slopes. The genus is dryopteroid in its morphology, but has been placed in a separate family Tectariaceae based on molecular cladonomic studies (Smith et al., 2006, 2008).

The estimated number of species range from 150 (Tryon and Tryon, 1982; Kramer et al., 1990) to 230 (Holttum, 1991; Ding et al., 2013). Holttum (1991) recognized 105 species of Tectaria from Malesia and deduced that South East Asia is its center of origin. In India, the genus Tectaria Cav. is having 24 species and a variety
(Fraser-Jenkins, 2008). This genus from Peninsula and Western Ghats was studied by various pteridologists during different times. Beddome (1883) has reported four species from South India. Blatter and d'Almeida (1922) reported six species from Bombay presidency. Manickam and Irudayaraj (1992) have reported only three species from the Western Ghats of South India. Fraser-Jenkins (2008) has revised pteridophytic flora of Indian subcontinent and reported six species viz., $T$. coadunata, $T$. gemmifera, $T$. paradoxa, T.polymorpha, T. trimenii, T. zeylanica. Recently, Patil et al. (2014), Antony et al. (2014) and Dubal et al. (2016) have added three more species viz. T. fuscipes, $T$. puberula and Tectaria polymorpha from Deccan Peninsula and Western Ghats respectively. Based on the present investigation, authors are reporting nine species viz., $T$. coadunata, $T$. fuscipes, $T$. gemmifera, $T$. paradoxa, $T$. polymorpha, T. puberula, T. trimenii, T. wightii and $T$. zeylanica for Deccan Peninsula and Western Ghats of India. Maximum diversity was observed in Western Ghats (09) whereas Deccan Peninsula nestled 05 species. 
476

\section{Materials and Methods}

Study area

The Deccan Peninsula and Western Ghats are biogeographic zones of India, which covers $35-40 \%$ of biodiversity of India. The Deccan Peninsula is a central highland comprises the Vindhya and Satpura hill ranges, Chhota Nagpur Plateau, Karnataka Plateau, Eastern Ghats and Tamil Nadu Plains (Gupta et al., 2000). The zone is relatively homogenous and ranges from semi-arid to moist deciduous or semi-evergreen type of climate. Whereas the Western Ghats runs from Tapti river in north to Kanyakumari in the south, along the west coast of peninsular India through the states viz., Gujarat, Maharashtra, Goa, Karnataka, Tamil Nadu and Kerala (Lakshminarayana et al., 2001). It is one of the 25 biodiversity 'hotspots' in the world (Myers et al., 2000) and is one of the major tropical evergreen forest regions in India, revealing enormous plant diversity. It is also considered as a major genetic estate with a rich biodiversity of ancient lineage.

\section{Plant collection and processing}

Tectaria Cav., species were collected from Deccan Peninsula and Western Ghats of India and processed under laboratory. The collected specimens were poisoned by dipping into $0.4 \%$ formalin for a day. They were dried and affixed on the herbarium sheets by using fevicol glue. The specimens were identified by using literature viz., Beddome (1883); Blatter and Almedia (1922) and Manickam and Irudayaraj (1992) and doubtful specimens were sent also to Prof. S. P. Khullar and Mr. Fraser-Jenkins to obtain their expert opinion.

\section{Results and Discussion}

The genus Tectaria is having great variation in its morphology viz., some species are having erect rhizome $(T$. fuscipes, T.paradoxa and T.polymorpha), some are having short to long creeping rhizome (T. coadunata, $T$.gemmifera, T.puberula, T. trimenii, T. wightii and T.zeylanica), few are dimorphic-subdimorphic ( $T$. fuscipes, $T$. paradoxa, $T$. polymorpha, $T$. trimenii and $T$. wightii), few are monomorphic (rarely subdimorphic) fronds (T. coadunata, T. gemmifera, T. puberula and T. zeylanica), many of them are having anastomosing veins with or without included veinlets (T. coadunata, T. gemmifera, $T$. polymorpha, $T$. puberula, $T$. trimenii, $T$. wightii and $T$. zeylanica) while some are having free veins along the costa ( $T$. fuscipes and $T$. paradoxa).

Key to Decan Peninsula and Western Ghats Tectaria species

1a. Fronds simply pinnate ..................................... 2

1 b. Fronds bipinnate or more pinnate ..................... 3

2a. Rhizome short creeping, lower pinnae bifurcate.....T. polymorpha

2b. Rhizome long creeping, lower pinnae not bifurcate..... T. wightii 3a. Plants monomorphic. 4

3b. Plants sub-dimorphic or dimorphic .................... 5

4a. Plants produce gemmae on the rachis...T. gemmifera

4b. Plants do not produce gemmae on the rachis........6

5a. Lamina pinnate-bipinnatifid; twined sori present...... T.puberula

5b. Lamina bipinnatifid to quadripinnatifid; twined sori absent.....T. coadunata

6a. Rhizome long creeping......................T. zeylanica

6b. Rhizome erect-short creeping ............................. 7

7a. Areoles present along the rachis and costa ............ 8

7b. Areoles absent ..................................T. paradoxa

8a. Fertile lamina winged ......................... T. trimenii

8b. Fertile lamina not winged.................. T. fuscipes

1. Tectaria coadunata (J.Sm.) C. Chr., Contrib. U. S. Natl. Herb. 26(6):331. 1931; Sledge, Kew Bull. 27:418. 1972; Manickam \& Irudayaraj, Pterid. FI. W. Ghats, 255257.1992; Khullar, Illu. Fern Fl. West Him. Vol. II, 432434. 2000; Pullaiah et al., Pterid. A. P. India, 140-141. 2003. Fraser-Jenkins, Tax. Rev. three hundred Ind. Subcont. Pterido. 315.2008.

Deccan Peninsula \& Western Ghats: Andhra Pradesh, Chhattisgarh, Gujarat, Jharkhand, Karnataka, Kerala, Madhya Pradesh, Maharashtra, Odisha, Tamil Nadu and West Bengal.

Ecological Note: It is very common species found above the $>500 \mathrm{~m}$ altitude (rarely $<500 \mathrm{~m}$ ) collected along the roadside or water current, growing below $32{ }^{\circ} \mathrm{C}$ temperature and $>25 \%$ atmospheric humidity.

Conservation status: $T$. coadunata is collected from different localities in Deccan Peninsula and Western Ghats. About 300-500 individuals were recorded per locality and the area of occupancy (AOO) is $200-350 \mathrm{~km}^{2}$. Therefore, as per IUCN categories and criteria (IUCN ver. 2017-1), it is assessed as least concerned species for Deccan Peninsula and Western Ghats.

2. Tectaria fuscipes (Wall. ex Bedd.) C. Chr. Contr. U.S. Natl. Herb. 26:290. 1931; Ching, Sinensia 2:14. 1931; Tagawa \& K. Iwats. South East Asian Stud. 5: 97. 1967; Fraser-Jenkins, Tax. Rev. Three hundred Ind. Subcont. Pterido. 315. 2008; Patil et al., J. Jap. Bot. 187-188. 2014.

Deccan Peninsula \& Western Ghats: Karnataka

Ecological note: It is an uncommon species found below $1200 \mathrm{~m}$ altitude (rarely $>1200 \mathrm{~m}$ ) collected along the roadside or water current, growing below $<25^{\circ} \mathrm{C}$ temperature and $>50 \%$ atmospheric humidity.

Conservation status: T. fuscipes is collected from Castle Rock, Ulvai, Dandlei, Anshi, Sirsi, Agumbe forest of Western Ghats. About 200-300 individuals were recorded at each locality. However, other regions yet to be explored completely and might be the species were distributed in similar ecological conditions. Hence, more floristic surveys are indeed to determine and document the full range of distribution of $T$. fuscipes. Therefore, according to IUCN (2012) criteria, at present this species is considered as data deficient (DD) for Deccan Peninsula and Western Ghats.

3. Tectaria gemmifera (Fee) Alston, Journal of Bot. 77:288. 1939; Fraser-Jenkins, Tax. Rev. three hundred Ind. Subcont. Pterido. 315. 2008.

Deccan Peninsula \& Western Ghats: Kerala. 
Ecological note: It is a unique species found above the $500 \mathrm{~m}$ altitude (rarely $<500 \mathrm{~m}$ ) collected along the roadside, growing below $25{ }^{\circ} \mathrm{C}$ temperature and $>50 \%$ atmospheric humidity.

Conservation status: T. gemmifera is collected from Wayanad, Western Ghats. About 50-100 individuals were recorded at the locality. However, other regions yet to be explored completely and might be the species were distributed in similar ecological conditions. Hence, more floristic surveys are indeed to determine and document the full range of distribution of $T$. gemmifera. Therefore, according to IUCN (2012) criteria, at present this species is considered as data deficient (DD) for Deccan Peninsula and Western Ghats.

4. Tectaria paradoxa (Fée) Sledge, Kew Bull. 27:413. 1972; Manickam \& Irudayaraj, Pterid. FI. W. Ghats, 255257. 1992; Fraser-Jenkins, Taxon. Revis. Ind. Subcont. Pterid. 626.2008.

Deccan Peninsula \& Western Ghats: Karnataka, Kerala and Tamil Nadu.

Ecological note: It is an endemic species found above the $500 \mathrm{~m}$ (rarely below the $500 \mathrm{~m}$ ) collected along the water current, growing below $25{ }^{\circ} \mathrm{C}$ temperature and above $50 \%$ atmospheric humidity.

Conservation status: T. paradoxa is an endemic species collected from Karnataka, Kerala and Tamil Nadu forest regions of Western Ghats. Populations of 100-150 individuals were observed per locality and the area of occupancy (AOO) is $100-150 \mathrm{~km}^{2}$. It is an endemic to Deccan peninsula and Western Ghats therefore, as per IUCN categories and criteria (IUCN ver. 2017-1), it is evaluated as Near Threatened (NT).

5. Tectaria polymorpha (Wall. ex Hook.) Copel. Philipp. J. Sci., Sect. C, Botany 2:413. 1907; Christensen, Contr. U.S. Natl. Herb. 26: 330. 1931; Sledge, Kew Bull. $27: 419$ (1972) \& Bot. J. Linn. Soc. 84:18 (1982); Nayar \& Kaur, Comp. Bedd., Handb. 51(1974); Dixit, Census 144(1984); Rajagopal \& Bhat, Indian Fern J. 15:21 (1998); Dubal et al., Indian Fern J. 33:206-211. 2016.

Deccan Peninsula \& Western Ghats: Andhra Pradesh, Chhattisgarh, Karnataka, Kerala, Madhya Pradesh, Maharashtra, Odisha and Tamil Nadu.

Ecological note: It is a common species found at an altitude the $100-1200 \mathrm{~m}$ (rarely $>1200 \mathrm{~m})$, collected along the roadside, growing in rock crevices or on cutting edges at temperature $<25^{\circ} \mathrm{C}$ and $>50 \%$ atmospheric humidity.

Conservation status: Tectaria polymorpha (Wall. ex Hook.) Copel. is collected from different North-East India, Eastern Himalaya's and Western Ghats. About 100-200 individuals were found per locality and the area of occupancy (AOO) 100-150 km2. Therefore, as per IUCN categories and criteria (IUCN ver. 2017-1), it is assessed as least concerned (LC) species for Deccan peninsula and Western Ghats.

6. Tectaria puberula (Desv.) C. Chr., Dansk Bot. Ark. 7:67. 1932; Antony et al., Indian Fern J. 31:139-142.

Deccan Peninsula \& Western Ghats: Kerala.

Ecological note: It is a rare species found at an altitude $1100 \mathrm{~m}$ collected along the earth bank in evergreen forest at temperature $<25^{\circ} \mathrm{C}$ and $>50 \%$ atmospheric humidity.

Conservation status: Tectaria puberula is collected only from Moozhiyar forests of Pathanamthitta district, Kerala, comes under Western Ghats region. Furthermore, we assume that this African element might be dispersed in similar ecological conditions. Hence, more floristic explorations are needed to define and document the full range of distribution of Tectaria puberula. Therefore, according to IUCN (2017 ver.-1) criteria, at present this species is considered as data deficient (DD).

7. Tectaria trimenii C. Chr., Index Filic. Suppl. 1. 1934; Sledge, Kew Bull. 27(3):422-423. 1972.

Deccan Peninsula \& Western Ghats: Karnataka, Kerala and Tamil Nadu.

Ecological note: This species is endemic to South India and Sri Lanka, which reported from evergreen forest of Nelliampathy, Hills and Agasthyamala for the Western Ghats.

Conservation status: Tectaria trimenii C. Chr. is collected from Nelliampathy Hills, Yana Forest and Agasthyamala of Western Ghats. Furthermore, we assume that the species might be dispersed in similar ecological conditions. Hence, more floristic explorations are needed to define and document the full range of distribution of Tectaria trimenii. Therefore, according to IUCN (2017 ver.-1) criteria, at present this species is considered as data deficient (DD).

8. Tectaria wightii (C.B.Clarke) Ching, Sinensia 2:28, t. 10. 1931; Sledge, Kew Bull. 27(3):422-423. 1972; Nayar \& Kaur, Comp. Bedd., Handb. 51(1974); Dixit, Census 145(1984); Manickam and Irudayaraj, Pterid. Fl. W. Ghats, 258-259.1992; Pullaiah et al., Pterid. AP., India, 142-143. 2003. Fraser-Jenkins, Tax. Rev. three hundred Ind. Subcont. Pterido., 317.2008.

Deccan Peninsula \& Western Ghats: Karnataka, Kerala and Tamil Nadu.

Ecological note: the species is collected at an altitude 200 $-900 \mathrm{~m}$, growing on cut surfaces along the roadside or on rock cervices at $<25^{\circ} \mathrm{C}$ and $>50 \%$ atmospheric humidity.

Conservation status: T. wightii is an endemic species collected from Karnataka, Kerala and Tamil Nadu forest regions of Western Ghats. About 100-200 individuals were found per locality and the area of occupancy (AOO) is 100$250 \mathrm{~km}^{2}$. It is an endemic to Deccan peninsula and Western Ghats therefore, as per IUCN categories and criteria (IUCN ver. 2017-1) it is evaluated as Near Threatened (NT).

9. Tectaria zeylanica (Houtt.) Sledge, Kew Bull. 27(3): 422-423. 1972; Sukumaran et al., Indian J. Forestry 30(3):331-332. 2008.

Deccan Peninsula \& Western Ghats: Kerala and Tamil Nadu.

Ecological note: A unique species producing rosette pinnae and trilobed fertile frond which makes unique in the genus.

Conservation status: T. zeylanica is collected from Western Ghats. Furthermore, we assume that the species might be dispersed in similar ecological conditions. Hence, more floristic explorations are needed to define the full range of distribution of Tectaria zeylanica. Therefore, according to IUCN (2017 ver.-1) criteria, at present species is considered as data deficient (DD). 
478

\section{Taxonomic note}

The occurrence of $T$. fuscipes and T. polymorpha in Western Ghats and Deccan Peninsula is questionable (Fraser-Jenkins, 2008). According to him species Tectaria fuscipes and T.paradoxa are two smaller species with dark or blackish stipe-base scales, which have often been confused under various other names and with each other. Therefore, neither T. fuscipes occurred in South India nor T. paradoxa occurred in North India. Similarly, T. wightii is a species related to T. polymorpha, and has often been reported under that name, especially from S. India. Therefore, $T$. wightii entirely replaces the T. polymorpha in S. India. However, during present investigation authors were collected the all the species viz., Tectaria fuscipes, T. paradoxa, T. polymorpha and T. wightii from different regions of Western Ghats and Deccan Peninsula of India.

In T. fuscipes rhizome is suberect-erect rhizome, having dark black stipe scale, dimorphic-subdimorphic fronds, with free veins and areoles along the costa whereas in T. paradoxa rhizome is erect, brown stipe scale, dimorphicsubdimorphic fronds, with free veins without areoles along the costa (Fig. 1). The main difference between these two species is presence of absence of areoles along the costa. If areoles are present species is $T$. fuscipes and if absent species is T.paradoxa.

Similarly, $T$. polymorpha is having short creeping to suberect rhizome, black-brown colored rhizome and stipe scales, subdimorphic-dimorphic fronds, with bifurcate lower pinnae. In contrast $T$. wightii is having short to long creeping, branched rhizome, black-brown rhizome and stipe scales, subdimorphic-dimorphic fronds, without bifurcate lower pinnae. The main differences in between these species are having short creeping-suberect or short-long creeping rhizome and bifurcate lower pinnae (Fig. 1). If the plants with short creeping-suberect rhizome and lower pinnae are bifurcate the species is $T$. polymorpha and if the plants with short-long creeping rhizome and without bifurcate lower pinnae the species is T. wightii. Therefore, authors herewith confirmed the occurrence of all the above said species were in South India especially in Western Ghats and Deccan Peninsula regions of India.
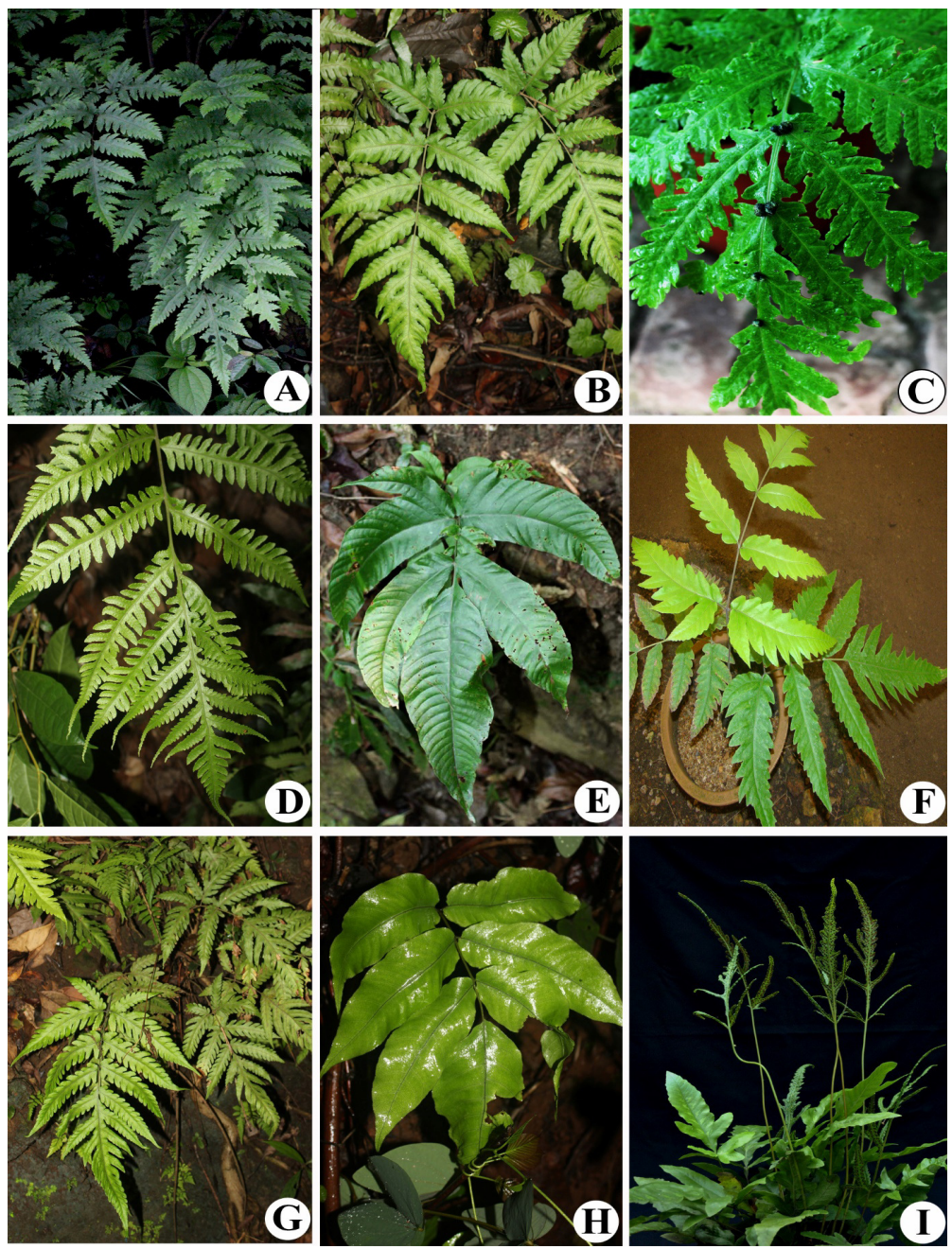

Fig. 1. Habit of different species of Tectaria collected from various parts of Peninsular and Western Ghats of India. A: Tectaria coadunata, B: T. fuscipes, C: T. gemmifera, D: T. parodoxa, E: T. polymorpha, F: T. puberula, G: T. trimenii, H: T. wightii and I: T. zeylanica 
Distribution of Tectaria species

As far as distribution concerned, the species were found from low altitude to high altitude, high to low moisture content, low to high temperature and along the roadside, earth bank or water current. The species viz., T. coadunata, T. polymorpha and T. wightii are found in both regions whereas T. fuscipes, T. gemmifera, T. puberula, T. paradoxa, T. zeylanica and T. trimenii are restricted to Western Ghats (Fig. 2). Amongst these $T$. paradoxa, T. trimenii and $T$. wightii are endemic species to South India and Sri Lanka whereas $T$. puberula and $T$. gemmifera are African species now naturalized in South India. All the species were growing happily in between $200 \mathrm{~m}$ to $1300 \mathrm{~m}$ (except $T$. coadunata grows up to $2000 \mathrm{~m}$ ) and if found above or below the given range the population is very low. Similarly, all the species were alive happily in between $13-25^{\circ} \mathrm{C}$ temperature and above $50 \%$ atmospheric humidity except $T$. coadunata grows up to $32{ }^{\circ} \mathrm{C}$ and survives happily up to $25 \%$ atmospheric humidity. Therefore $T$. coadunata is most common and distributed throughout the Western Ghats and Deccan peninsula.

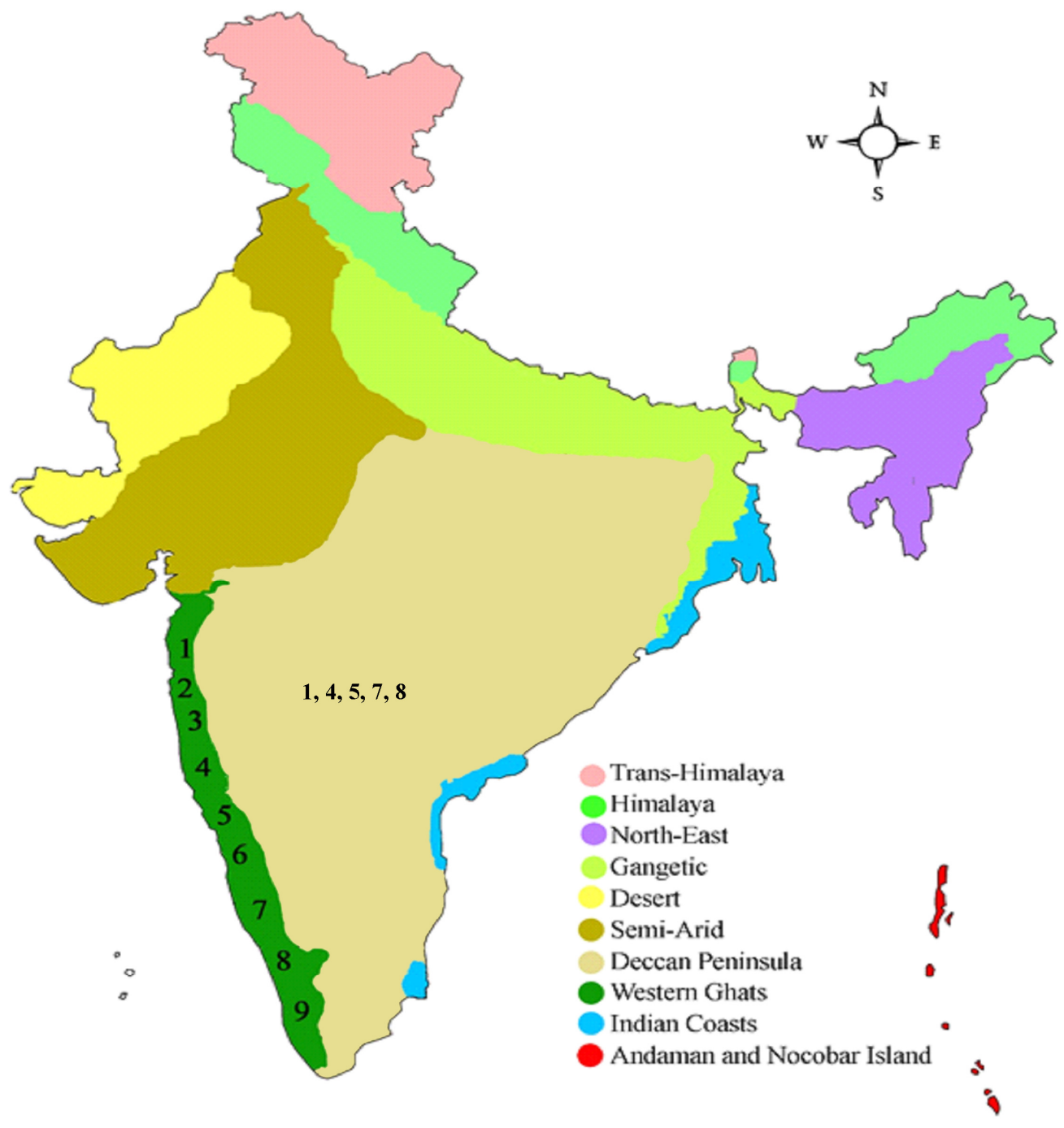

1. Tectaria coadunata

2. T. fuscipes

3. T. gemmifera

4. T. paradoxa

5. T. polymorpha
6. T. puberula

7. T. trimenii

8. T. wightii

9. T. zeilanica

Fig. 2. Diversity and distribution of Tectaria species in Western Ghats and Deccan Peninsula 
480

\section{Acknowledgement}

The authors are thankful to Science and Engineering Research Board (SERB) for financial support under NPDF program. We also thank Prof. S. P. Khullar (Emeritus Professor), and Mr. C. R. Fraser-Jenkins for the confirmation of the species identity. Thanks are also due to anonymous reviewers for their valuable suggestions on the earlier version of the manuscript.

\section{Conflict of Interest}

The authors declare that there are no conflicts of interest related to this article.

\section{References}

Antony R, Fraser-Jenkins CR, Mohanan M, Koshy CP (2014). Tectaria puberula (Desv.) C. Chr.(Dryopteridaceae: Pteridophyta), a new record for Asia. Indian Fern Journal 32:139-142.

Beddome RH (1883). Handbook to the ferns of British India, Ceylon and the Malay Peninsula. Thacker,Spink and Company.

BlatterE,D’Almeida JF (1922). The ferns of Bombay.DB Taraporevala and Sons \& Co, Bombay.

DingHH, Chao YS, CalladoJR, DongSY (2014). Phylogeny and character evolution of the fern genus Tectaria (Tectariaceae) in the old world inferred from chloroplast DNA sequences. Molecular Phylogenetics andEvolution 80:66-78.

Dixit RD (1984). A census of the Indian Pteridophytes. Flora of India. Ser.4, Botanical Survey of India, Howrah, Calcutta, India.

Dubal KN, Patil SM, Dongare MM, Kale MV (2014). Investigation of chemical composition from Dryopteris cochleata (D. Don) C. Chr. (Dryopteridaceae). Asian Journal of Pharmaceutical and Clinical Research 8(4):1-4.
Fraser-Jankins CR (2008). Taxonomic revision of three hundred Indian subcontinental Pteridophytes: with a revised census-list; a new picture of fern-taxonomy and nomenclature in the Indian subcontinent. Bishen Singh Mahendra Pal Singh.

Gupta HK, Sen KP, Balasubramanian D (2000). Deccan heritage. Indian National Science Academy. University Press (India) Limited pp 251.

Holttum RE (1991). New taxa in the Tectaria group (Polypodiaceae) from Malesia. Blumea 35(2):547-557.

Kramer KU, Holttum RE, Moran RC, Smith AR (1990). The families and genera of vascular plants. Vol 1. Pteridophytes and gymnosperms. Springer, Berlin pp 101-144.

Lakshminarayana KV, Yazdani GM, Radhakrishnan C (2001). Western Ghats in ecosystems of India. ENVIS-Zoological Survey of India, Kolkatapp 349-369.

Manickam VS, Irudayaraj I (1992). Pteridophytic flora of the Western Ghats-South India. Today and Tomorrows Publications, New Delhi, pp653.

Myers N, Mittermeier RA, Mittermeier CG, da Fonesca GAB, Kent J (2000). Biodiversity hotspots for conservation priorities. Nature 403(6772):853-858.

Patil SM, YadavSR, Dongare MM (2014). Tectaria fuscipes (Wall. ex Bedd.) C. Chr. (Tectariaceae, Pteridophyta), a new record for Southern India. The Journal of Japanese Botany 89:187-190.

Smith AR, Pryer KM, Schuettpelz E, Korall P, Schneider H, Wolf PG (2006). A classification for extant ferns. Taxon 55(3):705-731.

Smith AR, Pryer KM, Schuettpelz E, Korall P, Schneider H, Wolf PG (2008). Ferns and Lycophytes. Cambridge University Press, Cambridge pp 419-469.

Tryon RM, Tryon AF (1982). Ferns and allied plants with special reference to tropical America. Springer-Verlag, New Yorkpp 857. 